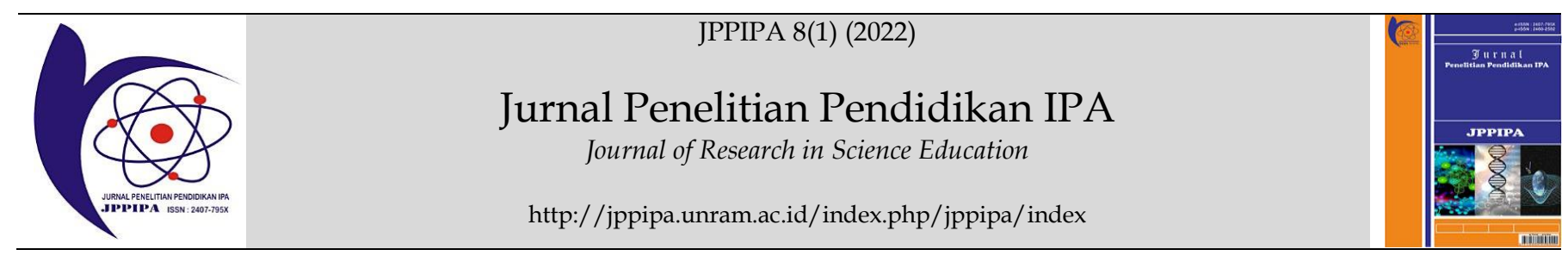

\title{
The strategy of Science Learning in Curriculum 2013 to Increase the Value of Science's Program for International Student Assessment (PISA)
}

\author{
Hartono $^{1 *}$, Ratu Ilma Indra Putri², Rita Inderawati ${ }^{3}$, Melly Ariska ${ }^{4}$ \\ ${ }^{1}$ Chemistry Education Study Program, Faculty of Teacher Training and Education, Universitas Sriwijaya, Indralaya, Indonesia. \\ ${ }^{2}$ Mathematic Education Study Program, Faculty of Teacher Training and Education, Universitas Sriwijaya, Indralaya, Indonesia. \\ ${ }^{3}$ English Language Education Study Program, Faculty of Teacher Training and Education, Universitas Sriwijaya, Indralaya, Indonesia. \\ ${ }^{4}$ Physics Education Study Program, Faculty of Teacher Training and Education, Universitas Sriwijaya, Indralaya, Indonesia.
}

\section{DOI: 10.29303/ippipa.v8i1.1185}

\section{Article Info}

Received: November 29, 2021

Revised: December 29, 2021

Accepted: January 6, 2022

Published: January 31, 2022

\begin{abstract}
Natural Science subjects consisting of Physics, Chemistry and Biology are given to all students starting from elementary school to equip students with logical, analytical, systematic, critical, and creative thinking skills, as well as the ability to work together. According to the Organization for Economic Cooperation and Development (OECD) in 2013, the conception of science literacy in the PISA (Program for International Student Assessment) supports the importance of students developing a solid understanding of the concepts of pure science and science education and the benefits involved in exploration in the abstract world that exists. on the universe. This study resulted in an analysis of science learning strategies for students of the Department of Science Education that support higher-order thinking skills in science. Two (2) parts of the material will be discussed more focus, namely (a) learning materials and (b) learning strategies. With the learning syllabus that supports the High Order Thinking Skills (HOTS) questions, the opportunity to increase the value of Science education (Physics, Chemistry, Biology) is greater, one of which is the preparation of challenging questions. Challenging science questions will meet the criteria for high-level questions (PISA has question levels from level 1 to level 6). HOTS questions support the development of a solid understanding of pure Science and Science Education concepts. The data sources used in the preparation of this research are the results of 2000, 2003, 2006, 2009, 2012, 2015, and 2018. PISA surveys and the 2013 curriculum book were sourced from the Ministry of Education and Culture.
\end{abstract}

Keywords: Natural Science; PISA; HOTS; Curriculum 2013

Citation: Hartono, H., Indra Putri, R. I., Inderawati, R., \& Ariska, M. (2022). The strategy of Science Learning in Curriculum 2013 to Increase the Value of Science's Program for International Student Assessment (PISA). Jurnal Penelitian Pendidikan IPA, 8(1), 79-85. https://doi.org/10.29303/jppipa.v8i1.1185

\section{Introduction}

In general, the quality of education, especially science education, is characterized by four criteria, namely: 1) the initial quality of students, 2) the use and selection of quality learning resources, 3) the learning process, and 4) educational output (Ariska, 2015). The quality of the learning process or learning success is basically a positive change during and after the learning process is implemented. This success can be seen from two sides, namely from the teacher's side and from the student's side. From the teacher's perspective, teaching success can be seen from the teacher's accuracy in choosing teaching materials, media, and 
learning tools used in an exciting, fun atmosphere, so that students can enjoy satisfying activities (Akhsan, et al., 2020; Saputri \& Zulkardi, 2019). In terms of students, teaching success can be seen from the emergence of a desire to learn independently which leads to an increase in cognitive, affective, and psychomotor aspects (Ariska, et al., 2021). The active involvement of students in the learning process and the positive changes caused by the teaching and learning process can be seen from the physical, intellectual, and emotional aspects during the teaching and learning process, as well as changing consciously or unconsciously after the teaching and learning process (OECD, 2014).

The benchmark for the level of quality of education can be seen from various aspects. If the managerial system used is based on education as a process, then the various steps taken by formal education providers are what determine the benchmark for successful performance (Novita, et al., 2012). One of the benchmarks for the quality of education used by the OECD (Organization for Economic Co-operation and Development) and used as a reference by the government is the results of the PISA (Program for International Student Assessment) test and survey. PISA is an examination system initiated by the OECD, to evaluate the education systems of 72 countries around the world (OECD, 2015), (OECD, 2016). Every three years, 15-year-old students are randomly selected to take a test of three basic competencies, namely reading, math and science. PISA measures what students know and what students can do (application) with their knowledge. PISA's main survey data collection is held every three years, namely in 2000, 2003, 2006, 2009, 2012, and 2015. The survey theme rotates every 3 years, and in 2015 the focus of the theme is scientific competence.

Some factors that cause low PISA scores in Indonesia are evaluation systems in schools that still use low-level questions, so students are not accustomed to solving high level problems (Stacey, 2011; Wu, 2011; Novita, 2012; Putri \& Zulkardi, 2019). In addition PISA questions use situations/phenomena that students can find in their daily lives, but in reality at school students are less accustomed to using contextual questions in everyday life that are designed and have characteristics and frameworks about PISA questions (Fatmawati, \& Ekawati, 2016). Though this has become one of the basic thoughts of developing the 2013 curriculum.

Faculty of Teacher Training and Education Universitas Sriwijaya (Unsri) is one of the institutions which produces teachers in South Sumatra, which has 4 majors and 15 study programs including Natural Sciences majors. As an institution which produces Natural Sciences teachers, FKIP Unsri must follow the development of education in the world, especially in Indonesia. To help student teacher candidate understand PISA questions, it is important to introduce them earlier so that the government's demands to improve the quality of education can be realized.

One of the subjects used by PISA as a benchmark for the quality of education in a country is science. Science is a field of study that is studied by all students from elementary to high school and also in universities. Science is an educational vehicle that has a significant contribution to the future of the nation, especially in the intellectual life of the nation. Science Literacy Ability can also shape students' personalities and develop certain skills (Cline, et al., 2020). By studying science people can develop the ability to think mathematically, logically, critically, and creatively which is really needed in everyday life. The reason for the need to study Science is because science is a means of clear and logical thinking, a means to solve problems of everyday life, a means of recognizing patterns of relationships and generalizing experiences, a means to develop creativity, and a means to raise awareness of cultural developments. Since Indonesia's participation in PISA, students' mastery of scientific literacy in Indonesia is still far behind compared to other countries.

From the three factors above, it can be seen that the quality of the learning process or the success of teaching and learning determines the relationship between science, educators, and students. Indonesian students do not yet have the ability to solve nonroutine problems or questions that are required to think higher. Thus, one of the things that need to be optimally developed is the ability to think at a higher level or known as HOTS.

Higher-order thinking skills High Order Thinking Skills (HOTS) consists of the ability to think logically, critically, systematically, analytically, creatively, productively, reasoning, connection, communication, and mathematical problem solving. One of the higher order thinking skills studied by the author is scientific literacy. Akhsan, (2019), stated that scientific literacy skills have not been maximally developed in schools in Indonesia. This can have an impact that students often have difficulty solving several problems in scientific literacy which in fact one science concept with other science concepts are interconnected.

The policy direction of the 2013 curriculum has emphasized science learning, especially in its assessment directed to be related to the actual abilities of students, based on student performance, can motivate learning, emphasize activities and student learning experiences, and give students freedom to construct their responses. For that (a) the development of indicators and learning materials, (b) the learning 
process, and (c) the evaluation provided must be able to develop divergent thinking skills, emphasize contexts that reflect the real world, use data obtained directly from the real world and use various methods and instruments (McKenna \& Robinson, 1990).

The Main question is what are the characteristics of activities that make Indonesian and American student teachers successfully familiar with the nature of the PISA Scientific Literacy Program and the PISA test items? The purposes of this study are to find out the difficulties of FKIP Unsri prospective teacher students on questions of natural science literacy; know the ability of natural science literacy for FKIP Universitas Sriwijaya and to produce teaching materials dealing with natural science literacy for prospective teacher students in FKIP Unsri.

One of the latest issues is in addition to the decline in the nation's competitiveness in terms of science literacy abilities, as well as how to prepare prospective natural science teacher students in high school in understanding natural science questions in accordance with the demands of the 2013 curriculum.

In this study, we will focus on the difficulties of prospective FKIP Unsri teacher in solving science literacy problems; know the ability of science literacy for prospective students FKIP Unsri teachers; and produce teaching materials about PISA that are valid and practical and can find out the role of teaching materials for prospective teacher students in FKIP Unsri.

\section{Method}

This research method is a descriptive study to find out the difficulties and abilities of FKIP Unsri prospective teacher students on reading, mathematics, and science literacy questions for prospective teacher students in FKIP Unsri. The subject of this research is prospective students semester 2, 4, and 6 study programs in the Science education at FKIP Universitas Sriwijaya.

Data collection techniques used in this study are by using questionnaires, interviews, and written tests. In this study, the questionnaire aims to find out the difficulties of prospective teachers of FKIP Unsri Science Study Program students in solving reading, mathematics, and sciences literacy questions. The questionnaire used will be a structured and unstructured questionnaire. In this study, the written test aims to measure the literacy skills of sciences for prospective teachers of FKIP Unsri in the Science education at FKIP Universitas Sriwijaya.

The interview is a method or method used to get an answer from the respondent by one-sided question and answer, verbally, face to face with the direction and purpose that has been determined. In this study, to obtain data directly from research subjects researchers will use a semi-structured interview. The purpose of the interview is to find out more about the students' process when completing the given reading, mathematics and natural science literacy questions.

After a written test, the students' answers are checked and scored according to the scoring guidelines that have been made for later analysis. After getting a score, do steps like the following: Change the score into a value form Student score obtained is then converted into grades using the following calculation rules (Tharp \& Gallimore, 1988).

$$
T=\frac{J S}{S M} X 100
$$

Information:

$T=$ Student Test Score

JS = Number of student scores

$S M=$ Maximum number of scores

Determine the percentage of the emergence of indicators of literacy skills Natural Sciences FKIP Unsri prospective teacher students. To determine the percentage of occurrence of literacy ability indicators, the following formula can be used (Ayoubi, et al., 2017)

$$
\text { percentage }=\frac{J S}{S M} \times 100 \%
$$

Information:

JS = Total score of the i-th aspect indicator

$S M=$ Maximum number of aspects score $\mathrm{i}$

Data analysis will be used qualitatively to illustrate the difficulties when literacy questions in science are accomplished. Interview Analysis Techniques with change the results of the interview to the form of interview transcription. The results of interviews that are still in the form of recordings are converted into written form in the form of interview transcriptions. After the interview transcription is made, the next thing to do is to code the important things. Things like sentences from research subjects indicate whether or not the student's mathematical communication skills appear. Study the information obtained to draw conclusions. The results of the interview transcript coding were then studied and only a few conversations were selected which did indicate whether or not the students' mathematical communication skills appeared. Which will be drawn later from the results of the interview analysis. At the end of the research stage, natural science literacy questions that have been tried out for prospective teacher students in FKIP Unsri will be collected into natural science literacy teaching materials. 


\section{Result and Discussion}

The subjects in this study were students of the Fourth semester of the Natural Science Education Study Program FKIP Sriwijaya University. Before taking data, the researchers first prepared questions that would be tested on students. The questions that will be tested are the original PISA Natural Science questions translated into Indonesian. Each PISA question content consists of level 1, level 2, and level 3 and in total there are 12 questions with objective types of questions and descriptions.

PISA framework-oriented questions, namely those containing content domains, context, competence, and attitudes. The PISA problem is a problem-solving that is resolved not only in one particular way. The following is a description of the criteria for grouping the questions: (1) Answer correctly with the right reasons during the interview; (2) Answer correctly with wrong reasons during the interview; (3) Write down solutions and wrong answers; (4) Wrong or no answer.

The questions are grouped into 3 levels, namely, at level 1a students are able to use a little content, procedural and epistemic knowledge to provide explanations, evaluate and design scientific inquiries and interpret data in a few familiar life situations that require a low level of cognitive demand. They are able to use a few simple sources of data, in a few contexts and can describe some very simple causal relationships. They can distinguish some simple scientific and nonscientific questions, and identify the independent variable in a given scientific inquiry or in a simple experimental design of their own. They can partially transform and describe simple data and apply them directly to a few familiar situations. Students can comment on the merits of competing explanations, interpretations of data, and proposed experimental designs in some very familiar personal, local and global contexts.

At Level 2, students are able to use content, procedural and epistemic knowledge to provide explanations, evaluate and design scientific inquiries and interpret data in some given familiar life situations that require mostly a low level of cognitive demand. They are able to 49 make a few inferences from different sources of data, in few contexts, and can describe simple causal relationships. They can distinguish some simple scientific and non-scientific questions, and distinguish between independent and dependent variables in a given scientific enquiry or in a simple experimental design of their own. They can transform and describe simple data, identify straightforward errors, and make some valid comments on the trustworthiness of scientific claims. Students can develop partial arguments to question and comment on the merits of competing explanations, interpretations of data and proposed experimental designs in some personal, local and global context.

At Level 3, students are able to use content, procedural and epistemic knowledge to provide explanations, evaluate and design scientific enquiries and interpret data in some given life situations that require at most a medium level of cognitive demand. They are able to draw a few inferences from different data sources, in a variety of contexts, and can describe and partially explain simple causal relationships. They can distinguish some scientific and non-scientific questions, and control some variables in a given scientific inquiry or in an experimental design of their own. They can transform and interpret simple data and are able to comment on the confidence of scientific claims. Level 3 students show some evidence of linked scientific thinking and reasoning, usually applied to familiar situations. Students can develop partial arguments to question and critically analyze explanations, models, interpretations of data, and proposed experimental designs in some personal, local and global contexts.

Data collection was carried out on July 5, 2021, through the edmodo.com platform, Students of the 4th semester of the Faculty of Teacher Training and Education of Sriwijaya University answered PISA questions through edmodo.com, and information related to PISA was also conveyed through Edmodo. The number of 4 th semester students in the class as respondents was 30 people, while the total number of students was 41 people. As many as 11 people were constrained by the signal so that they had difficulty responding via edmodo.com. After taking the test data using PISA questions and correcting them, then interviews were conducted with students with high, medium, and low abilities based on the results of student answers. Interviews were conducted in stages through zoom meetings, WA telephone, and other media.

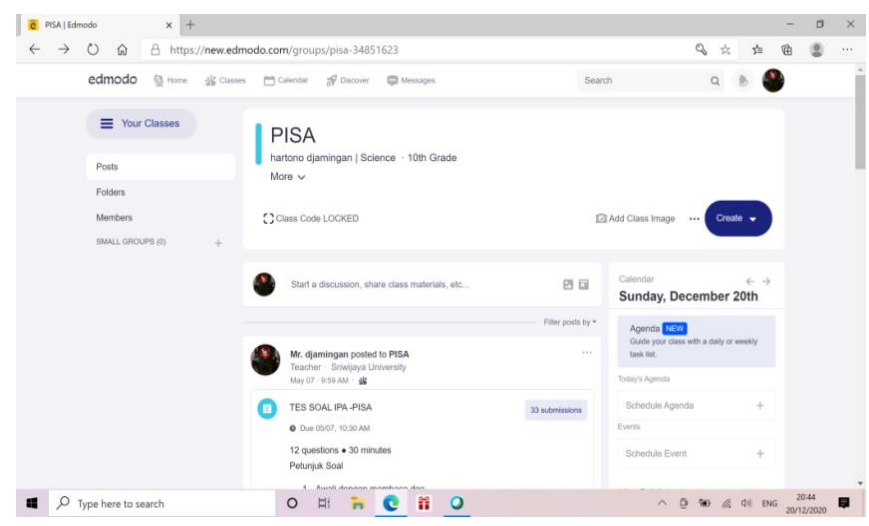

Figure 1. Program PISA in Edmodo.com 
Interview activities are carried out in stages according to the agreement with students. Interview material about the reasons for the answers to PISA questions that have been done on Edmodo. The data from the research results including test data and interview data were analyzed to determine how high the level of students' ability in solving questions and calculating the percentage. The percentage is based on the assessment categories that have been made. These categories are as follows: Based on the acquisition of student scores in completing 12 PISA questions with level 1 , level 2, and level 3, the percentage graph is obtained as figure 2 .

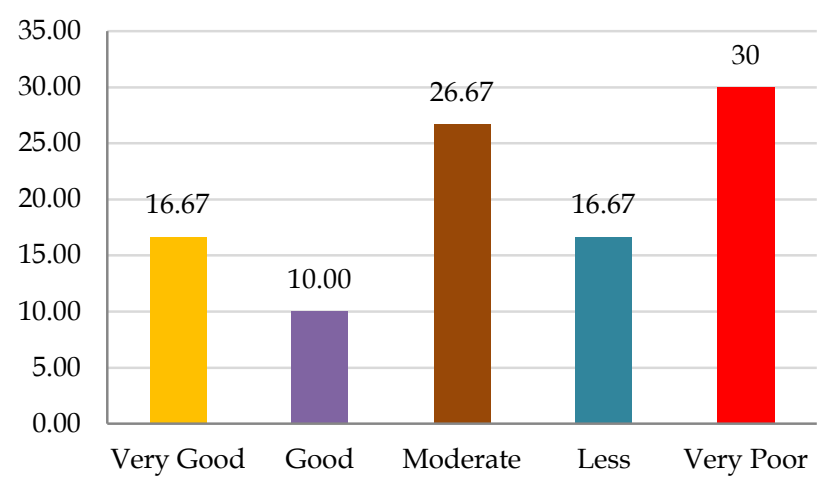

Figure 2. Students' Scores

From the graph, it was found that of the 30 students who worked on the PISA IPA questions, only 5 were in the very good category $(16.7 \%), 3$ students were in a good category $(10 \%), 8$ were in the moderate category $(26.7 \%), 10$ people were in the poor category $(16.6 \%)$, and 9 people were in the very poor category. This graph shows that the frequency of students in solving PISA questions which are categorized as less and very less is the most dominant, which is $46.6 \%$. This shows that the ability of prospective teacher students in solving PISA questions is still lacking. On the other hand, there are students who are categorized as very good. This student with the excellent category answered all the questions correctly and wrote down the solution. The following is a snippet of student answers that were categorized as very good.

Answer: While the bus break, the water will spill over side 2 because of Newton I Law. In Newton I Law "Everything will stay stable or move states except there is a force which works on its". From the student's answer, it can be seen that the strategy used by the student in answering questions is based on Newton's I law so that the resulting answer is based on the correct theory. This is based on Newton's Law I.
Snippets of interview results:

Interviewer (F): Assalamualaikum. Good afternoon Rozky. I am with Mrs. Nike from FKIP Sriwijaya University.

Please take a moment to be interviewed regarding the results of your PISA test answer Informant $(\mathrm{N})$ :

Waalaikumsalam. Okay, mom. I have opened and re-read the results of my answer yesterday P: Alhamdulillah, I started yes. I will re-read the results of your answer according to the answer that was written during yesterday's test. I will ask your reason for each answer. If there is a change in answer, or in doubt, please submit it later

$\mathrm{N}$ : Fine ma'am.

P: Question No 1. In answer No 1. Ananda answered D. "the water will spill but don't know whether it will spill on side 1 or side $2 "$. Why is that?

$\mathrm{N}$ : Sorry ma'am, when answering the question, I likened that I was with the water glass in a car. If the car suddenly brakes suddenly, then I will fall forward. But because water is a liquid, it will experience a shock on both sides, so you don't know which side it will fall on.

P: Ok thanks. I continued question number 2. In this question, you answered simply "correct. Because it is powered by an electric machine. Can you reiterate the reason?

$\mathrm{N}$ : in my opinion, it is correct ma'am. Buspowered by an electric machine will not contribute to environmental pollution. Because it doesn't use diesel or other fuels. So the resulting emissions are less.

P: Question no 3. Ananda answered C. why did he not choose points $\mathrm{A}, \mathrm{B}$, or D?

$\mathrm{N}$ : it's because I saw that the point of location $\mathrm{C}$ is close to the sea. So there is less chance of being affected by the volcano. Because of the far position

P: Question No 4. Ananda answered because volcanic eruptions released volcanic ash and sulfur dioxide into the atmosphere. So what does this condition have to do with the question of the percentage of solar radiation reaching the earth's surface due to eruptions?

$\mathrm{N}$ : To be honest, I don't really understand the condition of this phenomenon, ma'am. But in my opinion, when the eruption occurs, the volcano releases sulfur dioxide, which depletes the ozone layer. So the depletion of the ozone layer, the greater the percentage of solar radiation that enters the earth.

From the explanation above, it can be seen that if the 2013 curriculum targets are matched with PISA questions, then the two are appropriate/supportive. Thus, if the design of the Science lessons in the 2013 Curriculum is in accordance with the types of PISA 
Science questions, then with the PISA Science average score that is not yet maximized, the aspect that needs to be considered does not lie in the concept of science, but rather on the implementation of science learning in the field (Sukmana, 2018). The problem of achieving PISA standards lies with the teacher as the spearhead. In addition, another factor that affects the implementation of science learning according to the 2013 curriculum is the science teacher. Teachers at the SMP/MTs level must be able to facilitate structured science learning from LOTS to HOTS. This is non-negotiable. The UKG that has been implemented is expected to support the mastery of science concepts.

Mastery of learning strategies by teachers who support SLC (student learning center) and who can support HOTS is also important. This can only be achieved through patterned and sustainable process skills (core activities). Teachers must understand the steps for using learning strategies correctly. Learning strategies that are in accordance with HOTS demands, including Inquiry and Problem Based Learning. Both also meet the scientific approach used in the 2013 Curriculum (Aini \& Siswono, 2014).

In addition to science teachers, Indonesian language teachers must also achieve the 2013 curriculum target that demands HOTS, so students must be able to understand, master, and interpret sentences used in science questions correctly. There are many important Mathematics words that are expressed and implied (not immediately found by reading). Students have this ability only if the mastery of the language/question is carried out continuously and from an early age (from grade VII).

Students must be trained to have high learning motivation (not give up easily). In some schools, since grade VII, students have been identified which have an above-average IQ and which students have below it. Children with high abilities are given enrichment with more varied questions. This pattern is known as the identification of gifted children. Children with this group are actually ready to be required to think high order (HOTS) (Maulana \& Hasnawati, 2016; Rosalina, 2017).

School facilities in the form of teaching aids that support inquiry learning strategies and problem based learning must be complete. The learning culture in the classroom needs to be changed to give students the freedom to think and argue in order to create a critical attitude (Luke, et al., 1994; Saputri \& Zulkardi., 2020). By providing opportunities for students to convey new ideas or other innovations even though they are not the same as existing habits, it can create student creativity. Another factor that is no less important is that parental support for student activities, both at school and at home, still has a big influence
(Djaali \& Muljono, 2008). Parents must support in the form of motivation, provide various kinds of learning resources while at home, and play an active role in assisting children's learning.

\section{Conclusion}

Based on the results of the PISA-Science test for student science teacher candidates at the Universitas Sriwijaya, it was found that $46.6 \%$ of the students who worked on the PISA-Science questions the score category was "Less and very poor". Students are only able to solve PISA questions at a low level, while or higher levels there are still many students who make mistakes. These errors occur because students do not understand the facts properly and relate them to the concepts that underlie these facts. Even though students have used various metacognitive strategies, they still have difficulty solving PISA reading problems. This is evidenced by the results of answering Mocondo's narrative reading questions, only two students were correct using metacognitive strategies by activating knowledge at the beginning of reading and ending with strategies for making text summaries. Thus it can be concluded that the strategies used by students in solving problems depend on the peculiarities of the questions given.

\section{References}

Aini, R.N., \& Siswono, T.Y.E. (2014). Analisis Pemahaman Siswa SMP dalam Menyelesaikan Masalah Aljabar pada PISA. Jurnal Ilmiah Pendidikan Matematika. (33). 158-164. https://doi.org/10.1177/1362168812457537

Akhsan, H., Wiyono, K., Ariska, M., \& Melvany, N. E. (2020). Development of HOTS (higher order thinking skills) test instruments for the concept of fluid and harmonic vibrations for high schools. Journal of Physics: Conference Series, 1480(1). $\quad$ https://doi.org/10.1088/17426596/1480/1/012071

Ariska, M. (2015). Studi Pemahaman Konsep Siswa Pada Sub Konsep Rangkaian Listrik Arus Searah di Kelas Xi Sma Negeri 1 Palembang. J. Inov. dan Pembelajaran Fis., vol. 2, no. 2, pp. 147-154. https://doi.org/10.36706/jipf.v2i2.2616

Ariska, M. Akhsan, H. Muslim, M. and Azizah, S.N. (2021). Pemahaman Konsep Awal Mahasiswa Pendidikan Fisika Terhadap Materi Benda-Benda Langit. JIPF. 5(3). pp 224-235. https://doi.org/10.20527/jipf.v5i3.3523

Ayoubi, Z., El Takach, S., \& Rawas, M. (2017). Improving the pedagogical content knowledge 
(PCK) among cycle 3 in-service chemistry teachers attending the training program at the faculty of education, Lebanese University. Journal of Education in Science, Environment and Health (JESEH), $3(2)$,

196-212. https://doi.org/10.21891/jeseh.326753

Djaali, D., \& Muljono, P. (2008). Pengukuran dalam Bidang Pendidikan. Jakarta: PT. Grasindo.

Fatmawati, D., \& Ekawati, R. (2016). Pengembangan soal matematika PISA-like pada konten change and relationship untuk siswa sekolah menengah pertama. Jurnal Ilmiah Pendidikan Matematika, 2(5), 29-38. http://dx.doi.org/10.22342/jpm.8.1.1860.25-42

Luke A., Comber, B., \& O'Brien, J. (1994). Making community texts objects of study. Australian Journal of Language and Literacy. 17 (2), 139-145.

Maulana, A. \& Hasnawati. (2016). “Deskripsi Kemampuan Literasi Matematika Siswa Kelas VIII-2 SMP Negeri 15 Kendari." Jurnal Penelitian Pendidikan Matematika 4(2):1-14. http://dx.doi.org/10.31332/ai.v14i1.1109

McKenna, M.C., \& Robinson, R.D. (1990). Content literacy: A definition and implications. Journal of Reading, 34, 184-186. https:// doi.org/10.1080/13664530.2021.1935311

Novita, R., Zulkardi, Hartono, Y. (2012). Exploring primary students problem solving ability by doing tasks like pisa's question. Journal on Mathematics Education. 3(2), 133-150. http://dx.doi.org/10.1016/j.compedu.2019.01.01 $\underline{3}$

OECD. (2010). PISA 2009 Results: Executive summary. Paris: OECD Publishing.

OECD. (2016). PISA 2015: Result in focus. Paris: OECD Publishing.

OECD (2019). PISA 2018 Assessment and Analytcal Framework. Paris: OECD Publishing.

OECD. (2013). PISA 2012 assessment and analytical framework: Mathematics, reading, science, problem solving and financial literacy. Paris: OECD Publishing.

OECD. (2015). Assesment and analitycal framework. Paris: OECD Publishing

OECD. (2014). PISA 2012 Results: What students know and can do - student performance in mathematics, reading and science (Volume I, Revised edition, February 2014). Paris: OECD Publishing.

Putri, R.I.I., \& Zulkardi, 2019. Designing jumping task on percent using PMRI. International Journal on Emerging Mathematics Education (IJEME), 3(1), 105-116.

http://dx.doi.org/10.12928/ijeme.v3i1.12208

Rosalina, A.D. (2017). Profil Pemecahan Masalah PISA pada Konten Change and Relationship Siswa SMP Ditinjau dari Kecerdasan Linguistik, Logis Matematis, dan Visual-Spasial. Jurnal Ilmiah Pendidikan Matematika. 3(6). 53-62. https://doi.org/10.26740/mathedunesa.v6n3.p $\% 25 p$

Saputri, N. W., \&Zulkardi. (2020). Pengembangan LKPD pemodelan matematika siswa SMP menggunakan konteks ojek online. Jurnal Pendidikan Matematika, 14(1), 1-14 https://doi.org/10.22342/jpm.14.1.6825.1-14

Stacey, K. (2011). The PISA view of mathematical literacy in Indonesia. Journal on mathematics education. 2(2), 95-126. https://doi.org/10.22342/jme.2.2.746.95-126

Tharp, R.G., \& Gallimore, R. (1988). Rousing minds to life: Teaching, learning, and schooling in social context. New York: Cambridge University Press.

Wu, M. (2011). Using PISA and TIMSS Mathematics Assessments to Identify the Relative Strengths of Students in Western and Asian Countries. Journal of Research in Education Sciences, 56, 67-89. https://doi.org/10.3966/2073753X201103560100 $\underline{3}$. 